\title{
ОСОБЛИВОСТІ ІМУННОГО ПРОФІЛЮ У КРОВІ ЩУРІВ 3 ГОСТРИМ ПОШИРЕНИМ ПЕРИТОНІТОМ НА ТЛІ ГІПОТИРЕОЗУ
}

Вступ. Перитоніт залишається одним з найбільш частих ускладнень хірургічних захворювань органів черевної порожнини. За даними окремих авторів, при тяжких фрормах поширеного гнійного перитоніту летальність досягає 50-80 \%. Усе че вказує на необхідність подальшого вдосконалення методів діагностики і лікування даного патологічного процесу.

Мета дослідження - встановити особливості функціонування клітинної і гуморальної ланок імунної системи в щурів з гострим поширеним перитонітом на тлі експериментального гіпотиреозу.

Методи дослідження. У роботі використовували білих щурів лінії Вістар. Гіпотиреоз моделювали шляхом введення мерказолілу в дозі 25 мг/кг протягом 21-ї доби, гострий поширений перитоніт -введення 0,5 мл 10 \% профрільтрованої калової суспензії в черевну порожнину досліджуваних тварин. Визначали показники клітинної (CD4+-, CD8+-, CD22+-лімфоцитu) та гуморальної (імуноглобуліни (Ig) класів A, M, G) ланок імунітету. Тварин декапітували під тіопенталовим наркозом через 24 год, на 4-ту, 7-му і 10-ту доби від початку моделювання перитоніту.

Результати й обговорення. Як показали проведені дослідження, у тварин з гострим поширеним перитонітом на тлі гіпотиреозу суттєво знижувався показник CD4+-лімфроцитів, порушувалось співвідношення основних субпопуляцій лімфоцитів $\left(C D 4^{+} i C D 8^{+}\right)$, що супроводжувалось достовірним зменшенням імунорегуляторного індексу. Показовою була динаміка змін В-лімфроцитів CD22+, які є продуцентами імуноглобулінів. Ці зміни корелювали зі станом специфрічної гуморальної ланки імунітету - концентрацією імуноглобулінів у сироватці крові відповідних груп тварин. При моделюванні поширеного перитоніту в еутиреоїдних тварин ми виявили зниження концентрації IgG та зростання IgM й IgA. На тлі гіпотиреозу відзначали зменшення рівня імуноглобулінів усіх класів уже через 24 год тривалості патологічного процесу з подальшим зниженням до 10-ї доби. Показники імуноглобулінів усіх класів були також достовірно нижчими від аналогічних показників еутиреоїдних тварин з гострим поширеним перитонітом.

Висновки. У тварин з гострим поширеним перитонітом на тлі гіпотиреозу суттєво знижується показник CD4+-лімфоцитів, порушується співвідношення основних субпопуляцій лімфоцитів $\left(C D 4^{+} i C D 8^{+}\right)$, що супроводжується достовірним зменшенням імунорегуляторного індексу. Виявлена недостатність клітинної ланки імунної відповіді відображає посилення взаємного негативного впливу запального процесу в очеревині й системних порушень імунного захисту за умов супутнього гіпотиреозу. Існує прямий зв'язок між зниженим рівнем CD22+-лімфоцитів та показниками IgA й IgG. При гострому поширеному перитоніті на тлі мерказоліліндукованого гіпотиреозу порушується фоункціональність імунної системи, що проявляється дисбалансом імуноглобулінів у кров'яному руслі та зниженням резистентності гуморальної ланки імунної системи.

КЛЮЧОВІ СЛОВА: поширений перитоніт; гіпотиреоз; клітинний імунітет; гуморальний імунітет.

ВСТУП. Перитоніт залишається одним 3 найбільш частих ускладнень хірургічних захворювань органів черевної порожнини $[1,2]$. За даними окремих авторів, при тяжких фрормах поширеного гнійного перитоніту летальність досягає 50-80 \% [3-5]. Усе це вказує на необхідність подальшого вдосконалення методів діагностики і лікування даного патологічного процесу.

(c) Р. В. Верба, І. М. Кліщ, 2017.
Значна кількість ускладнень і летальних випадків при перитоніті зумовлена різноманітними патогенетичними механізмами, задіяними при даному патологічному процесі, багато з яких на сьогодні вивчено недостатньо [6]. Уявлення про провідні механізми перитоніту з плином часу зазнали певної трансорормації [2]. Тяжкість перебігу перитоніту залежить від адекватності імунної відповіді. Коректна імунна відповідь та достатні резерви компенсації організму сприя- 
ють локалізації вогнища запалення. Імунна недостатність зумовлює несприятливий перебіг перитоніту, її характеризують як вторинний набутий імунодефріцитний стан, що спричиняє розвиток ускладнень, сепсису та смерть хворих [7].

Знижене продукування тиреоїдних гормонів впливає на фрункції і стан багатьох органів та систем, зокрема імунної, що, у свою чергу, суттєво впливає на перебіг патологічних процесів за цих умов [8, 9]. Перебіг перитоніту на тлі зниження функції щитоподібної залози має свої особливості. Дія екзо- й ендогенних патогенів втягує в біологічну реакцію запалення не тільки імунокомпетентні органи, але і нейросекреторні клітини гіпоталамуса, які запускають перебудову функції ендокринної системи, спрямованої на адаптацію організму до умов патологічного процесу [10].

Окрім того, одним з компонентів сучасного комплексного лікування перитоніту, який не входить до стандартів лікування, $є$ імунокорекція. Сьогодні для імунотерапії використовують препарати, до складу яких входить комплекс імуноглобулінів (Ig) основних класів - A, M, G ( $\lg \mathrm{A}, \lg \mathrm{M}, \lg \mathrm{G})$. Однак роботи на цю тему свідчать про те, що дані препарати необхідно застосовувати з патогенетичної точки зору, своєчасно, у фазу перших проявів симптомів перитоніту й ураження органів, а їх пізніше використання як "терапія відчаю" $€$ патогенетично та економічно необґрунтованим і неефективним заходом [7].

Зважаючи на це, метою даного дослідження було вивчити вплив гіпотиреозу на клітинну і гуморальну ланки імунної системи при генералізованому перитоніті.

МЕТОДИ ДОСЛІДЖЕННЯ. Дослідження було проведено на білих щурах-самцях лінії Вістар, отриманих з віварію Тернопільського державного медичного університету імені І. Я. Горбачевського, відповідно до вимог Правил проведення роботи 3 використанням експериментальних тварин [11]. Тварини отримували звичайний раціон харчування та мали цілодобовий доступ до води. У кожну експериментальну групу методом випадкової вибірки включили по 12 щурів

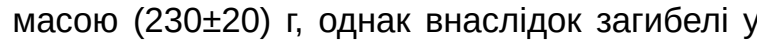
процесі експерименту їх кількість у групах на момент евтаназії була різною.

Гіпотиреоз моделювали шляхом щоденного введення per os за допомогою зонда фрармакопейного тиреостатика мерказолілу (“Здоров'я", Україна) в дозі 25 мг/кг протягом 21-ї доби [12]. Повноту досягнення гіпотиреозу контролювали, визначаючи концентрацію трийодтироніну і тироксину в сироватці крові, а також за динамікою маси тварин та їх рухової активності.
Вплив гіпотиреозу на перебіг гострого поширеного перитоніту вивчали на моделі, запропонованій В. А. Лазаренком і співавт. (2008) [13]. Модель полягає у введенні 0,5 мл 10 \% профрільтрованої калової суспензії в черевну порожнину досліджуваних щурів. Суспензію отримували шляхом змішування ізотонічного розчину і калу зі сліпої кишки 2-3 інтактних тварин, потім її двічі фрільтрували через подвійний шар марлі й через 20 хв після приготування вводили інтактним щурам пункційним способом. Щоб уникнути пошкодження внутрішніх органів, тварин тримали вертикально, каудальним кінцем угору. Методом пункції вентральної стінки в центрі середньої лінії живота, направляючи кінець голки по черзі у праве і ліве підребер'я, праву та ліву клубові ділянки, вводили однакову кількість калової суспензії.

Експериментальних тварин поділили на 4 групи: 1-ша - щури без змодельованої патології, яким перорально вводили дистильовану воду протягом 21-ї доби; 2-га - тварини, в яких моделювали гіпотиреоз шляхом перорального введення мерказолілу в дозі 25 мг/кг протягом 21-ї доби; 3-тя - щури, в яких моделювали гострий каловий перитоніт; 4-та - тварини, в яких моделювали гострий каловий перитоніт на тлі попередньо змодельованого гіпотиреозу.

Дослідження клітинної $\left(\mathrm{CD}^{+}, \mathrm{CD}^{+}, \mathrm{CD} 22^{+}\right)$ ланки імунітету проводили імунофрлуоресцентним методом за допомогою моноклональних антитіл до CD4 ${ }^{+}$-, CD8 ${ }^{+}$- і CD22 $2^{+}$-антигенів щура, кон'югованих із фрлуоресцеїн ізотіоціонатом (FITC) виробництва "Beckman Coulter" (США). Імунореактивність організму вивчали за вмістом сироваткових імуноглобулінів A, M, G методом твердофразового імуноферментного аналізу за допомогою набору реагентів "еBioscience, Inc" із використанням аналізатора "StatFax".

Тварин декапітували під тіопенталовим наркозом через 24 год, на 4-ту, 7-му і 10-ту доби від початку моделювання перитоніту. Для проведення досліджень використовували цільну кров та сироватку крові.

Статистичну обробку цифрових даних здійснювали за допомогою програмного забезпечення Excel i STATISTICA з використанням параметричних і непараметричних методів оцінки отриманих даних. Для всіх показників розраховували значення середньої арифметичної вибірки (М), ії̈ дисперсії і помилки середньої (m). Достовірність різниці значень між незалежними кількісними величинами визначали при нормальному розподілі за t-критерієм Стьюдента, в інших випадках - за допомогою U-критерію МаннаУїтні (достовірними вважали відмінності при $\mathrm{p}<0,05)[14]$. 
РЕЗУЛЬТАТИ Й ОБГОВОРЕННЯ. АНаЛіЗ показників клітинної ланки імунітету вказує на суттєві відмінності між досліджуваними групами тварин (табл. 1). У тварин з гіпотиреозом показник $\mathrm{CD} 4^{+}$-лімфоцитів був на $26 \%$ нижчим, ніж у щурів, у яких не моделювали патології. Дещо менше знижувався рівень $\mathrm{CD}^{+}$-лімсроцитів - на 10 \% від норми, що призвело до достовірного зменшення імунорегуляторного індексу 3

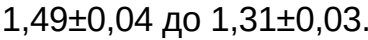

Моделювання гострого поширеного перитоніту супроводжувалося різноспрямованими змінами показників клітинної ланки імунітету. Зокрема, через 24 год від початку моделювання патологічного процесу в еутиреоїдних тварин показник $\mathrm{CD}^{+}$становив $126 \%$ від рівня щурів без патології, a $\mathrm{CD}^{+}-109 \%$, що спричинило зростання імунорегуляторного індексу в 1,17 раза. Достовірні зміни ми відмітили і на 4-ту добу: показник $\mathrm{CD}^{+}$склав 133 \% від норми, $\mathrm{CD}^{+}-$ $106 \%$. Такі зміни виражалися в ще більшому зростанні співвідношення $\mathrm{CD}^{+} / \mathrm{CD}^{+}$, яке стано-

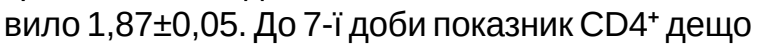
зменшився, однак на $23 \%$ перевищував рівень тварин, в яких не моделювали патологічного процесу. Незначне зростання показника $\mathrm{CD}^{+}$ (108 \% від норми) призвело до деякого знижен-

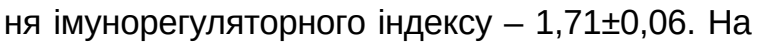
10-ту добу спостереження показник $\mathrm{CD} 4^{+}$залишився майже на тому ж рівні, що і в попередній термін спостереження, однак суттєвіше зменшення рівня Т-супресорів (94 \% від рівня тварин без змодельованої патології) спричинило значне збільшення співвідношення $\mathrm{CD} 4^{+} / \mathrm{CD}^{+}-$ $1,94 \pm 0,08$.

Отже, в еутиреоїдних щурів спостерігали нормальний перебіг запального процесу з переважанням зростання Т-хелперів над рівнем цитотоксичних Т-лімфоцитів і, відповідно, збільшенням імунорегуляторного індексу.

У тварин, в яких гострий поширений перитоніт моделювали на тлі гіпотиреозу, зміни мали дещо інше спрямування. Вміст CD4+-лімсооцитів через 24 год від початку моделювання гострого поширеного перитоніту на тлі гіпотиреозу, порівняно зі щурами без змодельованого патологічного процесу, достовірно знизився і становив 80 \% від їх рівня, що спричинило значне зменшення імунорегуляторного індексу - 1,32 $\pm 0,02$, це склало $75 \%$ від показника тварин без змодельованої патології. На 4-ту добу експерименту

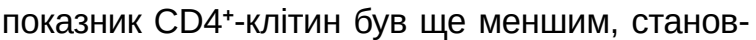
лячи 71 \% від норми, а CD8 ${ }^{+}-87 \%$. Імунорегуляторний індекс знизився ще більше і склав $1,22 \pm 0,02$, що на $53 \%$ менше, ніж у тварин без патології. До 7-ї доби вміст CD4+-лімфоцитів надалі знижувався, що, зважаючи на підвищен- ня показника $\mathrm{CD}^{+}$-лімфроцитів, призвело до ще більшого зменшення імунорегуляторного індексу - 1,08 $\pm 0,07$ порівняно з попереднім терміном спостереження, який був на $38 \%$ меншим від показника щурів без змодельованої патології. На 10-ту добу від початку моделювання гострого поширеного перитоніту у тварин, які вижили, показник $\mathrm{CD} 4^{+}$-лімфоцитів підвищився на $14 \%$ порівняно з попереднім терміном спостереження, що, зважаючи на незмінність вмісту Т-супресорів, спричинило зростання імунорегуляторного індексу до 1,22 $\pm 0,05$, який, однак, був достовірно нижчим, ніж у тварин без змодельованої патології, а також в еутиреоїдних щурів з поширеним перитонітом.

Таким чином, у тварин з гострим поширеним перитонітом на тлі гіпотиреозу суттєво знижувався показник $\mathrm{CD} 4^{+}-$-лімфроцитів, порушувалось співвідношення основних субпопуляцій лімфоцитів (CD4 ${ }^{+}$і CD8 $\left.{ }^{+}\right)$, що супроводжувалось достовірним зменшенням імунорегуляторного індексу. Виявлена недостатність клітинної ланки імунної відповіді відображала посилення взаємного негативного впливу запального процесу в очеревині й системних порушень імунного захисту за умов супутнього гіпотиреозу.

На сьогодні рівень імунорегуляторного індексу оцінюють у зіставленні з фразою імунної відповіді. У період розпалу клінічних проявів запального процесу цей індекс сягає високих значень за рахунок великого відсоткового вмісту Т-хелперів (CD4+ T-клітин). У період реконвалесценції значення показника зменшується у зв'язку з наростанням рівня CD8 ${ }^{+}$T-клітин. Порушення такої закономірності свідчить про неадекватність імунної реакції та можливість хронізації процесу через неповну ерадикацію збудника.

Для оцінки стану гуморальної ланки імунітету при гострому поширеному перитоніті на тлі гіпотиреозу було визначено рівень $\lg$, $\lg$ M, IgA в сироватці крові (табл. 2). Аналізуючи результати досліджень, можна констатувати, що спостерігались різноспрямовані зміни концентрації імуноглобулінів у сироватці крові щурів різних груп. Так, після моделювання гіпотиреозу рівень IgG зменшився в 1,3 раза, IgM - в 1,4 раза та $\lg$ A - в 1,6 раза. Результати наших досліджень свідчать про те, що гіпотиреоз призводить до зниження резистентності гуморальної ланки імунної системи при антигенній стимуляції та до вторинних імунодесріцитних станів.

Доведено, що у тварин з гострим поширеним перитонітом IgG через 24 год від моменту моделювання патологічного процесу становив $148 \%$, $\lg \mathrm{M}-128 \%$, a $\lg \mathrm{A}-139 \%$ стосовно щурів без патології. Гіперпродукування імуноглобулінів на 1-шу добу патологічного процесу свідчило про 

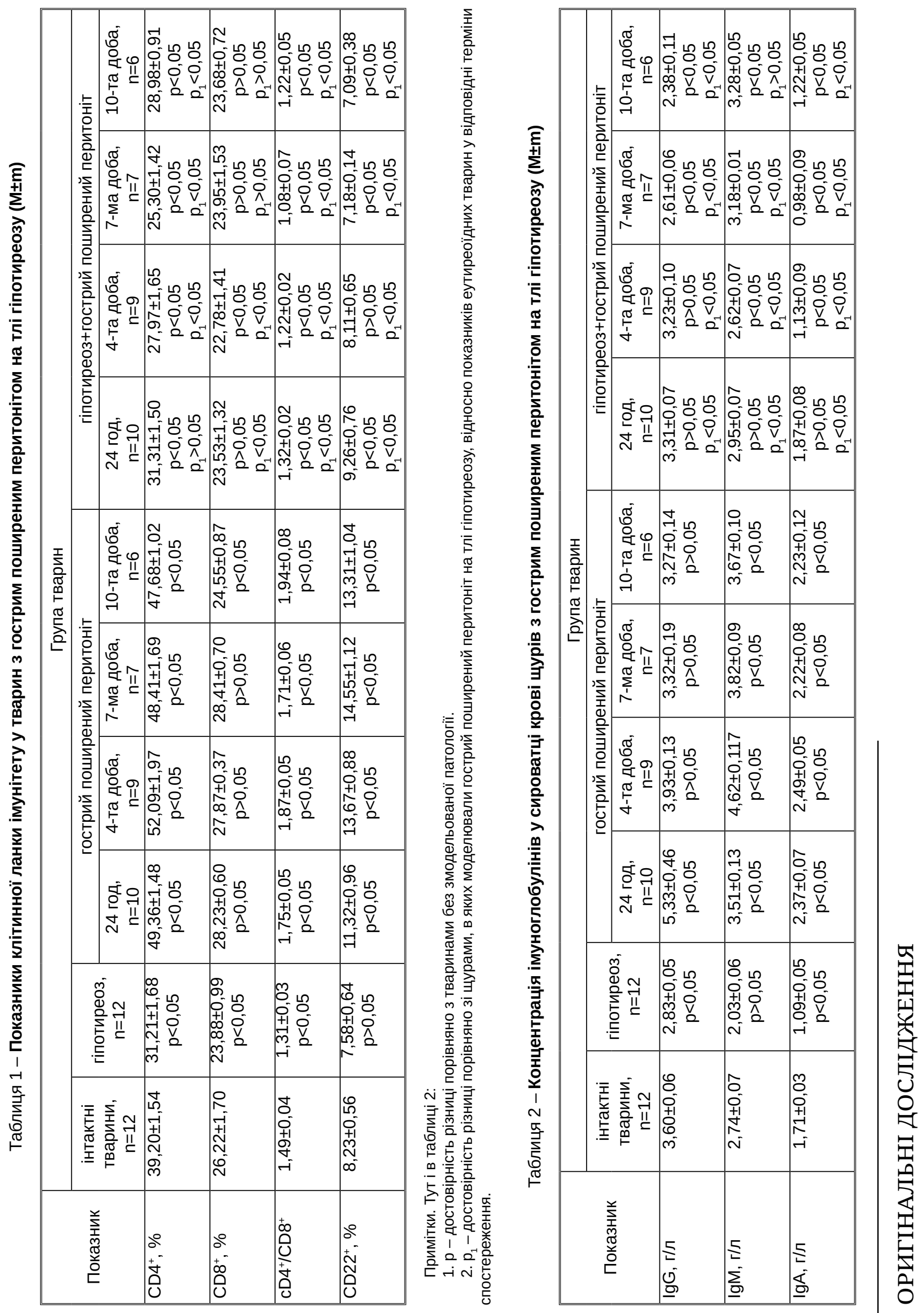
надлишок токсинів та антигенів при гострому поширеному перитоніті. У подальші терміни спостереження концентрація IgG поступово знижувалась і до 10-ї доби становила 91 \% від показника інтактних тварин. Водночас концентрація IgM та IgА зростала і на 4-ту добу спостереження складала, відповідно, 168 та 146 \% від рівня щурів без змодельованої патології. У подальші терміни показники дещо зменшувались, однак і до 10-ї доби концентрація IgМ становила 134 \%, IgA - 130 \% від норми. Ми вважаємо, що підвищення концентрації IgM та IgA можна пояснити тим, що вони є імуноглобулінами гострої фази запалення і недостатньо специсрічні для локалізації антигенного навантаження та есрективного завершення запалення, проте за недостатнього рівня IgG частково компенсаторно можуть взяти на себе його функції.

Потрібно відмітити, що при моделюванні гострого поширеного перитоніту на тлі гіпотиреозу ми відзначали зниження рівня імуноглобулінів усіх класів уже через 24 год тривалості патологічного процесу. Так, показники IgG та IgM були в 1,2 раза нижчими від аналогічних показників тварин без змодельованої патології, a IgA був меншим в 1,4 раза. Потрібно зауважити, що рівень імуноглобулінів у експериментальних тварин з гострим поширеним перитонітом на тлі гіпотиреозу значно перевищував показник щурів 3 гіпотиреозом. На 4-ту добу моделювання гострого поширеного перитоніту на тлі гіпотиреозу показник IgG зменшився і становив $90 \%$, тоді як рівень IgМ складав $96 \%$, a lgA- $66 \%$ відносно здорових тварин. До 7-ї доби концентрація IgG продовжувала знижуватись і показник складав 73 \% від норми, відповідно, IgМ зріс до $116 \%$, а $\lg$ А зменшився ще більше і становив $57 \%$ від рівня щурів без змодельованої патології. На 10-ту добу спостереження ми зафіксували подальше зниження показника IgG (66 \% від норми), подальше зростання рівня IgM (120\% від норми) та деяке підвищення, порівняно з попереднім терміном спостереження, концентрації $\lg A$, однак показник складав лише 71 \% від рівня щурів без змодельованої патології (табл. 2). Варто відмітити, що всі показники були також достовірно нижчими від аналогічних показників еутиреоїдних тварин $з$ гострим поширеним перитонітом.

Оскільки IgG є високоспецифічним імуноглобуліном, від вмісту якого залежать ефективність імунної відповіді та протиінфекційний захист, за сприятливого перебігу запального процесу його рівень повинен зростати щонайменше вдвічі [15]. Тому низький рівень IgG у тварин з гіпотиреозом $€$ прямою ознакою тяжкої імунної недостатності, передумовою ускладненого перебігу перитоніту та чітким імунним критерієм негативного прогнозу перебігу запалення.

Показовою була динаміка змін В-лімсроцитів $\mathrm{CD}_{22}{ }^{+}$, які $€$ продуцентами імуноглобулінів (табл. 1). Ці зміни корелювали зі станом специфрічної гуморальної ланки імунітету - концентрацією імуноглобулінів у сироватці крові відповідних груп щурів. Так, в еутиреоїдних тварин 3 гострим поширеним перитонітом встановлено чітку тенденцію до збільшення кількості CD22+ 3 максимумом на 7-му добу до $(14,55 \pm 1,12) \%$, що в 1,7 раза перевищувало показник щурів без змодельованої патології. За гострого поширеного перитоніту, що перебігав на тлі гіпотиреозу, спостерігали поступове зниження кількості CD22+ , і до 10-ї доби спостереження у тварин, які залишились живими, показник становив $(7,09 \pm 0,38) \%$, що на $16 \%$ менше, ніж у щурів без патології, та на 88 \% менше, ніж в еутиреоїдних тварин з гострим поширеним перитонітом. Це свідчить про те, що резерви організму щодо вироблення імуноглобулінів за умов дефіциту гормонів щитоподібної залози вичерпані, а це призводить до несприятливого перебігу патологічного процесу.

ВИСНОВКИ. 1. У тварин з гострим поширеним перитонітом на тлі гіпотиреозу суттєво знижується показник $\mathrm{CD} 4^{+}$-лімфоцитів, порушується співвідношення основних субпопуляцій лімфоцитів (CD4+ і CD8 ${ }^{+}$), що супроводжується достовірним зменшенням імунорегуляторного індексу. Виявлена недостатність клітинної ланки імунної відповіді відображає посилення взаємного негативного впливу запального процесу в очеревині й системних порушень імунного захисту за умов супутнього гіпотиреозу.

2. Існує прямий зв'язок між зниженим рівнем CD22+-лімфоцитів та показниками $\lg A$ й IgG.

3. При гострому поширеному перитоніті на тлі мерказоліліндукованого гіпотиреозу порушується фрункціональність імунної системи, що проявляється дисбалансом імуноглобулінів у кров'яному руслі та зниженням резистентності гуморальної ланки імунної системи. 


\section{СПИСОК ЛІТЕРАТУРИ}

1. Кацал В. А. Оптимізація програми комплексного передопераційного лікування хворих з поширеним гнійним перитонітом / В. А. Кацал // Клініч. хірургія. 2007. - № 10. - C. 18-21.

2. Blot S. Critical issues in the clinical management of complicated intra-abdominal infections / S. Blot, J. J. De Waele // Drugs. - 2005. - No. 65 (12). - P. 16111620.

3. Дзюбановський І. Я. Синдром поліорганної недостатності та його корекція у хворих на гострий поширений перитоніт / І. Я. Дзюбановський, Б. О. Мігенько // Український Журнал Хірургії. - 2009. - № 2. C. 56-59.

4. Increased postoperative peritoneal adhesion formation after the treatment of experimental peritonitis with chlorhexidine / A. Maleckas, V. Daubaras, V. Vaitkus, A. Aniuliene // Langenbeck's Arch. Surg. - 2004. - 389. P. 256-260.

5. Reed M. Acute bacterial peritonitis in adults / M. Reed, K. Parbadia, J. Cherian // US Pharm. - 2012. 37 (12). - P. HS1-HS8.

6. Van Westreenen M. Perioperative lavage promotes intraperitoneal adhesion in the rat / M. Van Westreenen, P. M. Van den Tol, A. Pronk // Eur. Surg. Res. - 1999. 31. - P. 196-201.

7. Пастернак І. І. Сучасна оцінка імунологічних показників у дітей з гострим деструктивним апендицитом, ускладненим поширеними формами перитоніту / І. І. Пастернак, Б. М. Боднар, Л. О. Безруков // Буковин. мед. вісн. - 2000. - 4, № 1-2. - С. 85-87.
8. Казмірчук В. Є. Клінічна імунологія і алергологія / В. Є. Казмірчук, Л. В. Ковальчук. - Вінниця : Нова книга, 2006. -526 с.

9. Паньків В. І. Синдром гіпотиреозу / В. І. Паньків // Междунар. эндокрин. журн. - 2012. - № 5 (45). C. 136-148.

10. Бажора Ю. І. Механізми макромолекулярних взаємодій у системному гомеостазі при фрормуванні первинної імунної відповіді в експерименті / Ю. І. Бажора, Ю. В. Петрашевич // Буковин. мед. вісн. - 2001. 5, № 3. - C. 162-167.

11. Науково-практичні рекомендації з утримання лабораторних тварин та роботи з ними / Ю. М. Кожем'якін, О. С. Хромов, М. А. Філоненко, Г. А. Сайфретдінова. - К. : Авіцена, 2002. - 156 с.

12. Isman C. A. Methimazole-induced hypothyroidism in rats ameliorates oxidative injury in experimental colitis / C. A. Isman, B. C. Yegen, I. Alican // J. Endocrinol. 2003. - 177, No. 3. - P. 471-476.

13. Экспериментальная модель распространенного калового перитонита / В. А. Лазаренко, В. А. Липатов, Ю. Ю. Блинков, Д. В. Скориков // Человек и его здоровье. - 2008. - № 4. - С. 128-132.

14. Лапач С. Н. Статистические методы в медико-биологических исследованиях с использованием Excel / С. Н. Лапач, А. В. Чубенко, П. Н. Бабич - К. : Морион, 2000. - 320 c.

15. Гордиенко А. И. Микротурбидиметрический метод определения IgG, IgM, IgA человека / А. И. Гордиенко, В. А. Белоглазов // Імунологія та алергологія. 2000. - № 1. - C. 12-15.

7. Pasternak, I.I., Bodnar, B.M., \& Bezrukov, L.O. (2000). Suchasna otsinka imunolohichnykh pokaznykiv u ditei z hostrym destruktyvnym apendytsytom, uskladnenym poshyrenymy formamy perytonitu [Modern assessment of immunological parameters in children with acute destructive appendicitis complicated by common forms of peritonitis]. Bukovynskyi medychnyi visnyk Bukovyna Medical Journal, 4, 1-2, 85-87 [in Ukrainian].

8. Kazmirchuk, V.Ye., \& Kovalchuk, L.V. (2006). Klinichna imunolohiia $i$ alerholohiia [Clinical immunology and allergology]. Vinnytsia: Nova knyha [in Ukrainian].

9. Pankiv, V.I. (2012). Syndrom hipotyreozu [Hypothyroidism syndrome]. Mezhdunarodnyy endokrinologicheskiy zhurnal - International Endocrinology Journal, 5 (45), 136-148 [in Ukrainian].

10. Bazhora, Yu.I., \& Petrashevych, Yu.V. (2001). Mekhanizmy makromolekuliarnykh vzaiemodii u systemnomu homeostazi pry formuvanni pervynnoi imunnoi vidpovidi v eksperymenti [Mechanisms of macromolecular interactions in systemic homeostasis in the formation of the primary immune response in the experiment]. Bukovynskyi medychnyi visnyk - Bukovyna Medical Journal, 5, 3, 162-167 [in Ukrainian].

11. Kozhemiakin, Yu.M., Khromov, O.S., Filonenko, M.A., \& Saifetdinova, H.A. (2002). Naukovo-prak- 
tychni rekomendatsii z utrymannia laboratornykh tvaryn ta roboty $z$ nymy [Scientific and practical advice on keeping laboratory animals and work with them]. Kyiv: Avitsena [in Ukrainian].

12. Isman, C.A., Yegen, B.C., \& Alican, I. (2003). Methimazole-induced hypothyroidism in rats ameliorates oxidative injury in experimental colitis. J. Endocrinol., 177 (3), 471-476.

13. Lazarenko, V.A., Lipatov, V.A., Blinkov, Yu.Yu., \& Skorikov, D.V. (2008). Eksperimentalnaya model rasprostranennogo kalovogo peritonita [Experimental model of widespread fecal peritonitis]. Chelovek $i$ yego zdorovye - Man and his Health, 4, 128-132 [in Russian].

14. Lapach, S.N., Chubenko, A.V., \& Babich, P.N. (2000). Statisticheskiye metody v mediko-biologicheskikh issledovaniyakh s ispolzovaniyem Excel [Statistical methods in biomedical research using Excel]. Kyiv: Morion [in Russian].

15. Gordiyenko, A.I., Beloglazov, V.A. (2000). Mikroturbidimetricheskiy metod opredeleniya $\lg$, $\lg$, $\lg A$ cheloveka [Microturbidimetric method for determination of human IgG, IgM, IgA]. Imunologiya ta alergologiya Immunology and Allergology, 1, 12-15 [in Russian].

Р. В. Верба, И. Н. Клищ ТЕРНОПОЛЬСКИЙ ГОСУДАРСТВЕННЫЙ МЕДИЦИНСКИЙ УНИВЕРСИТЕТ ИМЕНИ И. Я. ГОРБАЧЕВСКОГО

\section{ОСОБЕННОСТИ ИМУННОГО ПРОФИЛЯ В КРОВИ КРЫС С ОСТРЫМ РАСПРОСТРАНЕННЫМ ПЕРИТОНИТОМ НА ФОНЕ ГИПОТИРЕОЗА}

\section{Резюме}

Вступление. Перитонит остается одним из наиболее частых осложнений хирургических заболеваний органов брюшной полости. По данным отдельных авторов, при тяжелых фрормах распространенного гнойного перитонита летальность достигает 50-80 \%. Все это указывает на необходимость дальнейшего усовершенствования методов диагностики и лечения данного патологического прочесса.

Цель исследования - установить особенности фрункционирования клеточного и гуморального звеньев иммунной системы у крыс с острым распространенным перитонитом на фроне экспериментального гипотиреоза.

Методы исследования. В работе использовали белых крыс линии Вистар. Гипотиреоз моделировали путем введения мерказолила в дозе 25 мг/кг в течение 21-х суток, острый распространенный перитонит - введения 0,5 мл 10 \% профильтрованной каловой суспензии в брюшную полость исследуемых животных. Определяли показатели клеточного (CD4+-, CD8+-, CD22+-лимфроциты) и гуморального (иммуноглобулины классов A, M, G) звеньев иммунитета. Животных декапитировали под тиопенталовым наркозом через 24 ч, на 4-е, 7-е и 10-е сутки от начала моделирования перитонита.

Результаты и обсуждение. Как показали проведенные исследования, у животных с острым распространенным перитонитом на фроне гипотиреоза существенно снижался показатель CD4+-лимороцитов, нарушалось соотношение основных субпопуляций лимфоцитов $\left(C D 4^{+}\right.$и $\left.C D 8^{+}\right)$, что сопровождалось достоверным уменьшением иммунорегуляторного индекса. Показательной была динамика изменений B-лимфоцитов $C D 22^{+}$, которые являются продуцентами иммуноглобулинов. Эти изменения коррелировали с состоянием специфического гуморального звена иммунитета - концентрацией иммуноглобулинов в сыворотке крови соответствующих групп животных. При моделировании распространенного перитонита в эутиреоидных животных мы выявили снижение концентрации IgG и росm IgM u IgA. На фроне гипотиреоза отмечали уменьшение уровня иммуноглобулинов всех классов уже через 24 ч продолжительности патологического процесса с дальнейшим снижением до 10-х суток. Показатели иммуноглобулинов всех классов были также достоверно ниже аналогичных показателей эутиреоидных животных с острым распространенным перитонитом.

Выводы. У животных с острым распространенным перитонитом на фроне гипотиреоза существенно снижается показатель CD4+-лимфроцитов, нарушается соотношение основных субпопуляций лимсроцитов (CD4+ и $\left.C D 8^{+}\right)$, что сопровождается достоверным уменьшением иммунорегуляторного индекса. Обнаруженная недостаточность клеточного звена иммунного ответа отражает усиление взаимного негативного воздействия воспалительного прочесса в брюшине и системных нарушений иммунной защиты в условиях сопутствующего гипотиреоза. Существует прямая связь между пониженным уровнем CD22+-лимфоцитов и показателями IgA u IgG. При остром распространенном перитоните на фроне мерказолилиндуцированного гипотиреоза нарушается фрункциональность иммунной системы, что проявляется дисбалансом иммуноглобулинов в кровяном русле и снижением резистентности гуморального звена иммунной системы.

КЛЮЧЕВЫЕ СЛОВА: распространенный перитонит; гипотиреоз; клеточный иммунитет; гуморальный иммунитет. 


\section{PECULIARITIES OF IMMUNE PROFILE IN BLOOD OF RATS WITH AN ACUTE GENERAL PERITONITIS ON THE BACKGROUND OF HYPOTHYROIDISM}

\section{Summary}

Introduction. Peritonitis remains one of the most common complications of surgical diseases of the abdominal cavity. According to individual authors, in severe forms of disseminated purulent peritonitis, the mortality reaches 50-80\%. All this points to the need for further improvement of the methods of diagnosis and treatment of this pathological process.

The aim of the study - establishment of features of the immune system cellular and humoral units functioning in rats with acute widespread peritonitis on the background of experimental hypothyroidism.

Materials and Methods. White Wistar rats were used in the work. Hypothyroidism was modeled by the administration of Mercazolil at a dose of $25 \mathrm{mg} / \mathrm{kg}$ for 21 days. Acute common peritonitis was modeled by injecting $0.5 \mathrm{ml}$ of $10 \%$ filtered fecal suspension into the abdominal cavity of the animals under study. Cellular (CD4 ${ }^{+}, C D 8^{+}$, CD22+-lymphocyte) and humoral (IgA, IgM, IgG) immunity were measured. The animals were decapitated under thiopental anesthesia after 24 hours, on the $4^{\text {th }}, 7^{\text {th }}$ and $10^{\text {th }}$ days from the beginning of peritonitis modeling.

Results and Discussion. It was found that in animals with acute widespread peritonitis against hypothyroidism, there is a significant decrease in $C D 4^{+}$lymphocytes, a violation of the ratio of the main subpopulations of lymphocytes $\left(C D 4^{+}\right.$and $\left.C D 8^{+}\right)$, which is accompanied by a significant decrease in the immunoregulatory index. The dynamics of changes in B-lymphocytes $\mathrm{CD}_{22} 2^{+}$, which are producers of immunoglobulins, was indicative. These changes correlated with the state of specific humoral immunity - the concentration of immunoglobulins in the serum of the corresponding groups of animals. When simulating common peritonitis, euthyroid animals showed a decrease in IgG concentration and an increase in IgM and IgA. Against the background of hypothyroidism, we noted a decrease in the level of immunoglobulins of all classes after 24 hours of the duration of the pathological process with a further decrease to the tenth day. The indices of all classes of immunoglobulins were also significantly lower than those of euthyroid animals with acute widespread peritonitis.

Conclusions. In animals with acute common peritonitis, hypothyroidism is significantly reduced CD4+ lymphocytes, a violation of the ratio of the main subpopulations of lymphocytes $\left(C D 4^{+}\right.$and $\left.C D 8^{+}\right)$, which is accompanied by a significant decrease in the immunoregulatory index. The insufficiency of the cellular part of the immune response was found to reflect an increase in the mutual negative effect of the inflammatory process in the peritoneum and systemic disorders of immune defense in conditions of concomitant hypothyroidism. There is a direct relationship between the reduced level of CD22+ lymphocytes and the indices of immunoglobulins of classes $A$ and $G$. In acute widespread peritonitis against the background of mercazolil-induced hypothyroidism, there is a violation of the functionality of the immune system, manifested by an imbalance of immunoglobulins in the bloodstream and a decrease in the resistance of the humoral link of the immune system.

KEY WORDS: widespread peritonitis; hypothyroidism; cellular immunity; humoral immunity.

Адреса для листування: І. М. Кліщ, Тернопільський державний медичний університет імені І. Я. Горбачевського, майдан Волі, 1, Тернопіль, 46001, Україна, e-mail: klishch@tdmu.edu.ua. 